\title{
AUDIT DELAY PADA PERUSAHAAN PERTAMBANGAN : ANALISIS DAN FAKTOR-FAKTOR PENENTUNYA
}

\begin{abstract}
This study aimed to analyze the effect of firm size, firm size, solvency, and profitability to the audit delay. This study uses secondary data obtained from the Indonesia Stock Exchange. This population is a mining company listed on the Indonesia Stock Exchange during 2012-2014 period as many as 12 companies. The samples in this study using purposive sampling method. Performed during the observation period of 3 (three) years ie 2012-2014. Data analysis method used is multiple linear regression analysis. The results of the research that company size and profitability significantly influence audit delay. While the size of the firm and the solvency does not significantly influence audit delay.
\end{abstract}

Keywords : sudit delay, company size, firm size, solvency, and profitability.

\section{PENDAHULUAN}

Laporan keuangan merupakan instrumen yang penting bagi perusahaan Kusumawardani (2013). Hal ini dikarenakan laporan keuangan merupakan jembatan informasi antara pihak manajemen dengan pihak luar, namun pihak perusahaan biasanya melakukan upaya - upaya agar laporan keuangan terlihat lebih baik untuk menarik investor maupun dari pihak luar lainnya. Menurut BEI laporan keuangan harus diterbitkan tepat waktu dalam arti harus disampaikan sedini mungkin agar dapat digunakan sebagai dasar pengambilan keputusan dan untuk menghindari tertundanya pengambilan keputusan tersebut. Menurut Kusumawardani (2013) audit delay adalah waktu penundaan pelaporan laporan keuangan perusahaan yang diukur dari tanggal tutup buku laporan keuangan perusahaan hingga dipublikasikan di BEI. Di Indonesia, ketepatan waktu penyajian laporan keuangan perusahaan kepada publik diatur dalam UU No.8 Tahun 1995 tentang "Pasar Modal", diikuti dengan yang diikuti dengan Peraturan No. X.K.2 lampiran keputusan Ketua Bapepam-LK No. Kep-36/PM/2003 mengenai “Kewajiban Penyampaian Laporan Keuangan Berkala”, dan disempurnakan oleh Peraturan No. X.K.2 lampiran keputusan Ketua Bapepam-LK No. Kep-346/BL/2011 tentang “Penyampaian Laporan Keuangan Berkala Emiten dan Perusahaan Publik". Peraturan ini menyatakan bahwa laporan keuangan tahunan wajib disertai laporan akuntan dalam rangka audit atas laporan keuangan, dan disampaikan kepada Bapepam-LK paling lambat pada akhir bulan ketiga (90 hari) setelah tanggal laporan keuangan perusahaan.

Penelitian ini didukung dengan fenomena yang terjadi pada perusahaan tambang batubara milik Grup Bakrie, PT Bumi Resources Tbk (BUMI) menyatakan belum bisa mengeluarkan laporan keuangan tahunan 2014 karena perseroan masih berjibaku dengan perhitungan utang. (www.cnnindonesia.com, diakses tanggal 28 Mei 2015). Keinginan untuk menyajikan laporan keuangan tepat waktu sering dihadapkan dengan berbagai

Korespondensi dengan penulis: 
kendala. Salah satu kendala adalah adanya keharusan laporan keuangan untuk di audit oleh akuntan publik. Tujuan audit adalah untuk memberikan opini tentang kewajaran laporan keuangan, artinya bahwa laporan keuangan yang disajikan manajemen perlu verifikasi apakah telah sesuai dengan standar pelaporan yang berterima umum.

Pertama, penelitian tentang pengaruh ukuran perusahaan terhadap audit delay. Penelitian yang dilakukan oleh Puspitasari dan Sari (2012) menunjukkan bahwa total aset mempunyai pengaruh positif dan signifikan terhadap audit delay. Semakin besar total aset yang dimiliki oleh suatu perusahaan, maka semakin besar audit delay-nya. Menurt Hossain dan Taylor (1998) dalam Puspitasari dan Sari (2012) menyatakan bahwa perusahaan yang mempunyai total asset yang lebih besar akan menyelesaikan audit lebih lama dibandingkan dengan perusahaan yang mempunyai total aset lebih kecil, dikarenakan jumlah sampel yang harus diambil semakin besar dan semakin banyak prosedur audit yang harus ditempuh. Namun ada perbedaan dengan penelitian Kartika (2009) yang menyatakan bahwa ukuran perusahaan mempunyai pengaruh negatif dan signifikan terhadap audit delay. Semakin besar total aset yang dimiliki oleh suatu perusahaan maka semakin kecil audit delay-nya. Bertolak belakang dengan hasil penelitian Shultoni (2012) yang menyatakan ukuran perusahaan tidak berpengaruh terhadap audit delay.

Kedua tentang pengaruh ukuran KAP terhadap audit delay. Penelitian yang dilakukan Shultoni (2012) menyatakan bahwa ukuran KAP berpengaruh terhadap audit delay. Pada penelitian Iskandar dan Trisnawati (2010) menyatakan hal yang sama ukuran KAP berpengaruh terhadap audit delay bahwa auditor mempunyai reputasi yang baik, dalam hal ini adalah KAP big four akan memberikan kualitas pekerjaan audit yang efektif dan efisien sehingga audit dapat diselesaikan tepat waktu. Berbeda dengan hasil penelitian yang dilakukan oleh Febrianty (2011) menyatakan bahwa ukuran KAP tidak signifikan terhadap audit delay, menyatakan bahwa semakin baik kualitas KAP maka KAP tersebut belum memberikan jaminan terhadap kualitas audit yang dilakukan dengan salah satunya yakni ketepatan waktu dalam menyampaikan laporan keuangan

Ketiga, penelitian mengenai pengaruh solvabilitas terhadap audit delay. Penelitian yang dilakukan oleh Susilawati dan Agustina (2012) menyatakan bahwa solvabilitas positif signifikan terhadap audit delay. Penelitian Susilawati dan Agustina (2012) menyatakan bahwa rasio solvabilitas yang tinggi akan mengakibatkan panjangnya waktu yang dibutuhkan oleh auditor dalam mengaudit laporan keuangan. Hal yang sama juga dinyatakan pada penelitian Aryaningsih dan Budiartha (2014) Bahwa ketika perusahaan mempunyai tingkat solvabilitas yang tinggi, maka audit delay yang dilakukan oleh auditor terindikasi semakin panjang. Mengaudit akun hutang akan memakan waktu lama karena harus mencari penyebab dari tingginya proporsi hutang. Berbanding terbalik dengan hasil penelitian Rachmawati (2008) menyatakan bahwa solvabilitas tidak berpengaruh signifikan terhadap audit delay.

Keempat, penelitian tentang pengaruh profitabilitas terhadap audit delay. Hasil riset Ekstrini dan Laksito (2013) menyatakan bahwa profitabilitas berpengaruh terhadap audit delay, hal ini disebabkan karena besarnya profitabilitas perusahaan dapat menjadi kemudahan bagi auditor dalam melakukan proses audit. Dengan demikian proses penyelesaian audit dapat dilakukan secepatnya oleh KAP. Perusahaan dengan profitabilitas yang tinggi akan diaudit lebih tepat waktu dibandingkan perusahaan yang memiliki operasi gagal atau yang

Jurnal Akuntansi Indonesia 
mengalami kerugian. Hal ini karena perusahaan yang mendapatkan kerugian akan memerlukan proses audit yang lebih panjang. Auditor membutuhkan banyak waktu untuk mengaudit perusahaan yang gagal (resiko tinggi) sebagai pencegahan atas tuntutan hukum (litigasi) potensial di masa yang akan datang.

Berdasarkan hal-hal diatas, masih terdapat perbedaan hasil penelitian yang mempengaruhi audit delay. Oleh karena itu diperlukan penelitian lebih lanjut mengenai faktor-faktor yang mempengaruhi audit delay. Berdasarkan pengumuman penyampaian pelaporan keuangan interim yang berakhir pada 31 maret 2015, terdapat 565 total perusahaan yang tercatat dengan jumlah 423 perusahaan telah tepat waktu menyampaikan laporan keuangan, 76 perusahaan belum menyampaikan laporan keuangan, 8 perusahaan belum wajib menyampaikan laporan keuangan, dan 58 perusahaan tidak wajib menyampaikan laporan keuangan (www. idx.co.id, diakses pada 30 Mei 2015).

Sehingga variabel dependen yang akan diteliti adalah audit delay. Sedangkan variabel independen dalam riset ini adalah ukuran perusahaan, ukuran KAP, solvabilitas, dan profitabilitas. Pemilihan sektor pertambangan dijadikan sampel penelitian karena sektor ini sedang mengalami perkembangan, permintaan hasil tambang meningkat karena adanya kebutuhan nyata akibat arus investasi yang masuk, interaksi lintas negara, dan globalisasi. Berdasarkan uraian permasalahan di atas, maka rumusan masalah dalam penelitian ini adalah apakah ukuran perusahaan, ukuran KAP, solvabilitas, dan profitabilitas berpengaruh terhadap audit delay.

\section{TELAAH PUSTAKA}

\section{Teori Agensi (Agency Theory)}

Jensen dan Meckling (1976) dalam Febrianty (2011) menyatakan hubungan agensi muncul ketika satu orang atau lebih (principal) mempekerjakan orang lain (agent) untuk memberikan suatu jasa, kemudian mendelegasikan wewenang pengambilan keputusan kepada agen tersebut. Maksimalisasi kekayaan ini dilakukan oleh manajemen yang disebut sebagai agen. Ketidakmampuan atau keengganan manajemen untuk meningkatkan kekayaan pemegang saham menimbulkan apa yang disebut masalah keagenan (agency problem). Menurut Jensen (1986) dalam Febrianty (2011), agency problem timbul karena orang cenderung untuk mementingkan dirinya sendiri dan munculnya konflik ketika beberapa kepentingan bertemu dalam suatu aktivitas bersama.

Konflik kepentingan mendasari adanya biaya keagenan. Prinsipal termotivasi mengadakan kontrak untuk mensejahterahkan dirinya dengan profitabilitas yang selalu meningkat Febrianty (2011), tanpa adanya masalah mengenai kewajiban jangka pendek maupun jangka panjang yang terlalu besar sehingga mempengaruhi profitabilitas perusahaan, sedangkan agen termotivasi untuk memaksimalkan pemenuhan kebutuhan ekonomi dan psikologisnya. Agen sebagai pengelola kekayaan perusahaan, menyusun laporan keuangan yang kemudian diperiksa dan diberikan opini atas kewajaran laporan keuangan oleh pihak ketiga yakni akuntan publik sebagai sarana akuntabilitas agen kepada prinsipal. Teori agensi menjelaskan hubungan positif antara ukuran perusahaan dengan pengungkapan berdasarkan keuntungan potensial dari pengungkapan yang meningkat dengan biaya agensi Hossain et al., (1995) dalam Febrianty (2011).

\section{Teori Sinyal (Signalling Theory)}


Isyarat atau signal adalah tindakan yang diambil oleh manajemen perusahaan dimana manajemen mengetahui informasi yang lebih lengkap dan akurat mengenai internal perusahaan dan prospek perusahaan di masa depan daripada pihak investor. Oleh karena itu, manajer berkewajiban memberikan sinyal mengenai kondisi perusahaan kepada para stakeholder. Sinyal yang diberikan dapat dilakukan melalui pengungkapan informasi akuntansi seperti publikasi laporan keuangan. Manajer melakukan publikasi laporan keuangan untuk memberikan informasi kepada pasar. Umumnya pasar akan merespon informasi tersebut sebagai suatu sinyal good news atau bad news.

\section{Laporan Keuangan}

Laporan keuangan merupakan ringkasan dari suatu proses pencatatan, merupakan suatu ringkasan dari transaksi-transaksi keuangan yang terjadi selama tahun buku yang bersangkutan Baridwan (2004). Laporan keuangan dibuat oleh manajemen bertujuan untuk mempertanggungjawabkan tugas-tugas yang dibebankan kepadanya oleh para pemilik perusahaan. Selain itu laporan keuangan juga digunakan untuk memenuhi tujuan-tujuan lain yaitu sebagai laporan kepada pihak-pihak diluar perusahaan.

\section{Audit}

Audit adalah suatu proses sistematik untuk memperoleh dan mengevaluasi bukti secara objektif mengenai pernyataan-pernyataan tentang kegiatan dan kejadian ekonomi, dengan tujuan untuk menetapkan tingkat kesesuaian antara pernyataan-pernyataan tersebut dengan kriteria yang telah ditetapkan, serta penyampaian hasil-hasilnya kepada pemakai yang berkepentingan (Mulyadi, 2002:9). Tujuan umum suatu audit atas laporan keuangan adalah memberikan suatu pernyataan pendapat mengenai apakah laporan keuangan klien telah disajikan secara wajar, dalam segala hal material, sesuai dengan prinsip akuntansi berlaku umum.

\section{Audit Delay}

Menurut Shultoni (2012) audit delay didefinisikan sebagai lamanya waktu antara berakhirnya tahun fiskal perusahaan sampai dengan tanggal laporan audit yang diukur secara kuantitatif (jumlah hari). Audit delay ini akan menimbulkan dampak terhadap ketepatan publikasi informasi, dan informasi yang dipublikasikan dapat mempengaruhi penjualan kenaikan atau penurunan harga saham.

\section{Ukuran Perusahaan}

Keputusan ketua Bapepam No. Kep. 11/PM/1997 menyebutkan perusahaan kecil dan menengah berdasarkan aktiva (kekayaan) adalah badan hukum yang memiliki total aktiva tidak lebih dari seratus milyar, sedangkan perusahaan besar adalah badan hukum yang total aktivanya diatas seratus milyar. Pada dasarnya Ukuran Perusahaan hanya terbagi pada tiga kategori, yaitu perusahaan besar (large firm), perusahaan menengah (medium size), dan perusahaan kecil (small firm). Estrini dan Laksito (2013) menyatakan Ukuran perusahaan dapat dihitung menggunakan :

$$
\text { Ukuran Perusahaan }=\text { Diproksikan menggunakan total aset }(\text { LnSize }) \text {. }
$$




\section{Ukuran KAP}

Menurut Febrianty (2011) Kantor Akuntan Publik adalah lembaga yang memiliki izin dari Menteri Keuangan sebagai wadah bagi akuntan publik dalam menjalankan pekerjaanya. Pengukuran Kantor Akuntan Publik dibagi menjadi dua yaitu KAP the big four dan KAP non the big four. Hal ini juga menunjukkan kualitas dari KAP tersebut. Adapun kategori the big four di Indonesia yaitu:

1. KAP Price Waterhouse Coopers (PWC), bekerjasama dengan KAP Drs. Hadi Sutanto \& Rekan, Haryanto Sahari \& Rekan.

2. KAP Klynveld Peat Marwick Goerdeler (KPMG), bekerjasama dengan KAP Sidharta- Sidharta \& Widjaja.

3. KAP Ernest \& Young (E \& Y), bekerjasama dengan KAP Prasetio, Sarwoko, \& Sanjadja.

4. KAP Deloitte Touche Thomatsu (Deloitte), bekerjasama dengan KAP Hans Tuanakotta \& Mustofa, Osman Ramli Satrio \&Rekan. Ukuran KAP menggambarkan jenis KAP yang mengaudit laporan keuangan perusahaan dengan kode 1 untuk KAP Internasional (big four) dan kode 0 untuk KAP lokal (non big four) Shultoni (2012).

\section{Solvabilitas}

Variabel Solvabilitas merupakan jumlah proporsi hutang yang dimiliki oleh perusahaan. Solvabilitas dapat pula diartikan sebagai perbandingan antara jumlah hutang dengan jumlah ekuitas yang dimiliki perusahaan. Aryaningsih dan Budiartha (2014) menyatakan solvabilitas dapat dihitung dengan rumus:

$$
\text { DER }=\frac{\text { Total hutang } \times 100 \%}{\text { Total ekuitas }}
$$

\section{Profitabilitas}

Profitabilitas adalah ukuran mengenai kemampuan perusahaan dalam menghasilkan keuntungan selama periode tertentu. Menurut Katika (2009) profitabilitas sebagai dasar pemikiran bahwa tingkat keuntungan dipakai salah satu cara untuk menilai keberhasilan efektivitas perusahaan, tentu saja berkaitan dengan hasil akhir dari berbagai kebijakan dan keputusan perusahaan yang telah dilaksanakan oleh perusahaan dalam periode berjalan. Profitabilitas dapat dihitung menggunakan Estrini dan Laksito (2013):

$$
\mathrm{ROA}=\frac{\text { Laba setelah pajak } \times 100 \%}{\text { Total aset }}
$$

\section{Hubungan Logis Antar Variabel dan Perumusan Hipotesis Pengaruh Ukuran Peusahaan terhadap Audit Delay}

Hasil penelitian Puspitasari dan Sari (2012) menunjuk bahwa total asset mempunyai pengaruh terhadap audit delay. Karena semakin besar total asset yang dimiliki oleh suatu perusahaan, maka semakin besar audit delay-nya. Hossan dan Taylor (1998) dalam Puspitasari dan Sari (2012) menyatakan bahwa perusahaan yang mempunyai total assetyang lebih besar akan menyelesaikan audit lebih lama dibandingkan dengan perusahaan yang mempunyai total aset yang lebih kecil, hal ini dikarenakan jumlah sampel yang harus diambil semakin besar dan semakin banyak prosedur audit yang harus ditempuh. Hasil penelitian Rachmawati (2008), Kartika 
(2009), Febrianty (2011) dan Prabowo dan Marsono (2013) juga menyatakan bahwa total aset berpengaruh terhadap audit delay, maka hipotesis yang diajukan adalah :

H1 : Ukuran perusahaan berpengaruh terhadap audit delay.

\section{Pengaruh Ukuran KAP terhadap Audit Delay}

Rachmawati (2008) menyatakan bahwa ukuran KAP berpengaruh terhadap audit delay. Iskandar dan Trisnawati (2010) menyatakan bahwa auditor yang mempunyai reputasi baik (KAP the big four) akan memberikan kualitas pekerjaan audit yang efektif dan efisien. Karena KAP yang besar biasanya memiliki kemampuan untuk memberikan insentif yang besar untuk mempercepat proses audit sehingga tidak terjadi keterlambatan dan untuk mempertahankan reputasi KAP. Namun berbeda dengan hasil penelitian Febrianty (2011) yang menyatakan bahwa ukuran KAP tidak berpengaruh terhadap audit delay, semakin baik kualitas KAP maka KAP tersebut belum memberikan jaminan terhadap kualitas audit yang dilakukan dengan salah satunya yakni ketepatan waktu dalam menyampaikan laporan keuangan. Maka hipotesis yang akan diajukan adalah :

\section{H2 : Ukuran KAP berpengaruh terhadap audit delay.}

\section{Pengaruh Solvabilitas terhadap Audit Delay}

Semakin tinggi solvabilitas sebuah perusahaan akan mengakibatkan panjangnya proses laporan keuangan. Sejalan dengan penelitian Susilawati dan Agustina (2012), Puspitasari dan Sari (2012), Aryaningsih dan Budiartha (2014), dan Prabowo dan Marsono (2013). Aryaningsih dan Budiartha (2014) menyatakan bahwa solvabilitas berpengaruh signifikan terhadap audit delay. Mengaudit akun hutang akan memakan waktu lama karena harus mencari sumber penyebab dari tingginya proporsi hutang yang dimiliki oleh perusahaan serta membutuhkan banyak waktu dalam mengkonfirmasi pihak-pihak (debtholder) yang berkaitan dengan perusahaan. Kemampuan perusahaan untuk melunasi hutang-hutangnya pada kenyataannya sangat mempengaruhi proses audit. Maka hipotesis yang diajukan adalah :

\section{H3 : Solvabilitas berpengaruh terhadap audit delay.}

\section{Pengaruh Profitabilitas terhadap Audit Delay}

Hasil penelitian Estrini dan Laksito (2013) menyatakan besarnya profitabilitas perusahaan dapat menjadi kemudahan bagi auditor dalam melakukan proses audit. Dengan demikian proses penyelesaian audit dapat dilakukan secepatnya oleh KAP. Perusahaan dengan profitabilitas yang tinggi akan diaudit lebih tepat waktu dibandingkan perusahaan yang memiliki operasi gagal atau yang mengalami kerugian. Hal ini karena perusahaan yang mendapatkan kerugian akan memerlukan proses audit yang lebih panjang. Auditor membutuhkan banyak waktu untuk mengaudit perusahaan yang gagal (resiko tinggi) sebagai pencegahan atas tuntutan hukum (litigasi) potensial di masa yang akan datang. Prabowo dan Marsono (2013) juga menyatakan bahwa profitabilitas berpengaruh terhadap audit delay. Maka hipotesis yang diajukan adalah :

\section{H4 : profitabilitas berpengaruh terhadap audit delay.}




\section{Kerangka Pemikiran}

Kerangka pemikiran yang menggambarkan hubungan antara ukuran perusahaan, ukuran KAP, solvabilitas, dan profitabilitas terhadap audit delay

\section{METODE PENELITIAN}

\section{Variabel Penelitian dan Definisi Operasional}

Variabel terikat dalam penelitian ini adalah audit delay. Audit delay didefinisikan sebagai lamanya waktu antara berakhirnya tahun fiskal perusahaan sampai dengan tanggal laporan audit, yang diukur secara kuantitatif (jumlah hari). Sedangkan variabel bebas dalam penelitian ini adalah ukuran perusahaan, ukuran KAP, solvabilitas, dan profitabilitas.

\section{Ukuran Perusahaan}

Ukuran perusahaan adalah jumlah aset yang dimiliki perusahaan klien yang tercantum pada laporan keuangan perusahaan pada akhir periode yang telah diaudit. Variabel ini diproksikan dengan menggunakan total aset (LnSize) Estrini dan Laksito (2013) dan Shultoni (2012).

\section{Ukuran KAP}

Ukuran KAP merupakan variabel independen yang menggambarkan jenis KAP yang mengaudit laporan keuangan perusahaan dengan memberikan kode 1 untuk KAP Internasional (bigfour) dan kode 0 untuk KAP lokal (non bigfour) Shultoni (2012).

\section{Solvabilitas}

Variabel Solvabilitas merupakan jumlah proporsi hutang yang dimiliki oleh perusahaan. Solvabilitas diukur menggunakan rasio DER yaitu jumlah kewajiban dibagi dengan jumlah ekuitas Aryaningsih dan Budiartha (2014).

$$
\text { DER }=\frac{\text { Total hutang }}{\text { Total ekuitas }} \times 100 \%
$$

\section{Profitabilitas}

Profitabilitas adalah ukuran mengenai kemampuan perusahaan dalam menghasilkan keuntungan. Profitabilitas diukur dengan total laba bersih setelah pajak dibagi dengan total aktiva Estrini dan Laksito (2013).

$$
\mathrm{ROA}=\frac{\text { Laba setelah pajak }}{\text { Total aktiva }} \times 100 \%
$$

\section{Populasi dan Sampel}

Populasi yang digunakan dalam penelitian ini adalah semua perusahaan pertambangan yang terdaftar di BEl tahun 2012-2014. Metode pengambilan sampel dalam penelitian ini menggunakan metode purpose sampling. Adapun kriteria-kriteria yang digunakan untuk pemilihan sampel adalah sebagai berikut : 
1. Perusahaan tersebut terdaftar pada BEI tahun 2012 sampai dengan tahun 2014 dan masuk dalam kategori perusahaan pertambangan.

2. Perusahaan-perusahaan yang mempublikasikan laporan keuangan auditan lengkap secara berturut berturut pada tahun 2012 sampai dengan tahun 2014.

3. Laporan keuangan perusahaan memakai mata uang Rupiah secara berturut - turut pada tahun 2012 sampai dengan tahun 2014.

\section{Jenis Data, Sumber Data, dan Metode Pengumpulan Data}

Jenis data yang digunakan dalam penelitian ini adalah data sekunder. Data tersebut berupa laporan keuangan perusahaan pertambangan yang terdaftar di BEl dan data yang dipublikasikan tahun 2012-2014. Data sekunder yang digunakan dalam penelitian ini diperoleh dari Indonesia Stock Exchange (IDX) Bursa Efek Indonesia Kantor Perwakilan Semarang dan Perpustakaan Pusat Informasi Pasar Modal (PIPM) yang beralamat di J. M.H. Thamrin No. 152 Semarang. Metode pengumpulan data yang digunakan dalam penelitian ini adalah metode dokumentasi.

\section{Metode Analisis}

Analisis yang digunakan dalam riset ini adalah model regresi linier berganda. Metode analisis yang digunakan dalam penelitian ini adalah sebagai berikut :

1. Statistik Deskriptif

memberikan gambaran atau deskripsi suatu data yang dilihat dari nilai rata -rata (mean), standardeviasi, varian, maksimum, minimum, sum, range, kurtosis, danskewness Ghozali (2011:19). Dengan mengetahui data tersebut peneliti dapat memperoleh gambaran mengenai data penelitan atau pun sampel penelitian tersebut.

2. Uji Asumsi Klasik

Digunakan untuk mengetahui ada atau tidaknya normalitas residual, multikolinearitas, autokorelasi, dan heteroskedastis pada model regresi. Harus terpenuhinya asumsi klasik karena agar diperoleh model regresi dengan estimasi yang tidak bias dan pengujian dapat dipercaya Priyatno (2014:89).

a. Uji normalitas

Bertujuan untuk menguji apakah dalam model regresi, variable pengganggu atau residual memiliki distribusi normal. Salah satu cara untuk mendeteksi apakah residual berdistribusi normal yaitu uji statistik yang digunakan untuk menguji normalitas residual adalah uji statistik non-parametrik Kolmogorov-Smirnov Ghozali (2011:160)

b. Uji Multikolineritas

Bertujuan untuk menguji apakah model regresi ditemukan adanya korelasi antar variable bebas (independen). Model regresi yang baik seharusnya tidak terjadi korelasi antara variable independen. Untuk menunjukkan adanya multikolinearitas adalah nilai Tolerance $\geq 0,10$ atau sama dengan nilai 
VIF $\leq 10$ Ghozali (2011:105).

c. Uji Autokorelasi

Bertujuan menguji apakah dalam model regresi linear ada korelasi antara kesalahan pengganggu pada periode t-1 (sebelumnya). Autokorelasi muncul karena observasi yang berututan sepanjang waktu berkaitan satu sama lainnya, hal ini sering ditemukan pada data runtut waktu ( time series). Run test merupakan sebagian dari statistic non parametrik yang dapat digunakan untuk menguji apakah antar residual terdapat korelasi yang tinggi atau tidak Ghozali (2011:110).

d. Uji Heteroskedastisitas

Bertujuan untuk menguji apakah dalam suatu model regresi terjadi ketidaksamaan variance dari residual satu pengamatan kepengamatan yang lain Ghozali (2011:139). Uji heteroskedastisitas dalam penelitian ini dilakukan dengan Uji Glejser dengan cara meregresikan antara variable independen dengan nilai absolute residualnya.

\section{Pengujian Hipotesis}

a. Analisis Regresi Linier Berganda

Analisis regresi pada dasarnya adalah studi mengenai ketergantungan variabel dependen dengan satu atau lebih variabel independen dengan tujuan untuk mengestimasi dan atau memprediksi rata-rata populasi atau nilai rata-rata variable dependen berdasarkan nilai variabel independen yang diketahui Gujarati (2003) dalam Ghozali (2011:95). Pengujian hipotesis dilakukan dengan model regresi linear berganda. Model yang digunakan adalah :

$$
A U D=\alpha+\beta 1 S I Z E+\beta 2 K A P+\beta 3 S O L V A+\beta 4 P R O F I T+\varepsilon
$$

Keterangan:

$\begin{array}{ll}\text { AUD } & \text { : Audit delay } \\ a & : \text { Constanta } \\ \text { SIZE } & : \text { Ukuran perusahaan. } \\ \text { KAP } & : \text { Ukuran KAP. } \\ \text { SOLVA } & \text { : Solvabilitas. } \\ \text { PROFIT } & \text { : Profitabilitas. } \\ \varepsilon & : \text { Koefisien error. }\end{array}$

b. Uji Signifikansi Simultan (Uji Statistik F)

Uji statistik F pada dasarnya menunjukkan apakah semua variabel independen atau bebas yang dimasukkan dalam model mempunyai pengaruh secara bersama-sama terhadap variabel dependen/terikat. Perlu diketahui untuk menguji hipotesis menggunakan statistik $F$ yakni dengan membandingkan nilai $F$ hasil perhitungan dengan nilai $F$ menurut tabel. Bila nilai $F$ hitung lebih besar dari pada nilai F tabel, maka Ho ditolak dan menerima HA Ghozali (2011:98).

c. Uji Statistikt (Uji Signifikan Parameter Individual) 
Uji statistikt pada dasarnya menunjukkan seberapa jauh pengaruh satu variable penjelas/independen secara individual dalam menerangkan variasi variabel dependen Ghozali (2011:98). Pengujian secara terpisah untuk melihat apakah masing-masing variabel independen dapat berpengaruh terhadap audit delay. Pengujian dilakukan dengan meregresi audit delay pada variabel ukuran perusahaan, ukuran KAP, solvabilitas, dan Profitabilitas. Signifikansi berpengaruh variabel independen terhadap dependen dapat dilihat dari signifikansi t. uji $t$ dapat dilihat dari besarnya probabilitas ( $p$ value) dibandingkan dengan 0,05 (taraf signifikansi $\alpha=5$ persen). Apabila nilai signifikansi lebih kecil dari 0,05 maka hipotesis diterima, artinya variabel independen secara parsial mempengaruhi variabel dependen.

d. Uji Koefisien Determinasi $\left(R^{2}\right)$

Koefisien determinasi $\left(\mathrm{R}^{2}\right)$ pada intinya mengukur seberapa jauh kemampuan model menerangkan variasi variabel dependen. Nilai $\mathrm{R}^{2}$ yang kecil berarti kemampuan variabel-variabel independen dalam menjelaskan variabel dependen sangat terbatas Ghozali (2011:97).

\section{HASIL DAN PEMBAHASAN}

Berdasarkan tabel 1 dan 2 hasil perhitungan deskriptif tersebut dapat dijelaskan bahwa terdapat jumlah sampel (n) sebanyak 36 diperoleh dari hasil penilaian rata-rata audit delay pada perusahaan pertambangan yang terdaftar di BEI tahun 2012 - 2014 selama periode pengamatan sebesar 66,92 dengan standart deviasi sebesar 17,19 . Nilai mean sebesar 66,92 menunjukkan bahwa rata-rata audit delay perusahaan sampel adalah 66 hari. Jarak yang cukup besar antara nilai minimum dan maksimum dari audit delay dimana nilai minimum sebesar 17 hari dan nilai maksimum sebesar 87 hari.

1. Ukuran Perusahaan

Berdasarkan tabel diatas nampak bahwa dari 12 perusahaan pertambangan selama 3 tahun periode pengamatan ukuran perusahaan pada perusahaan pertambangan yang terdaftar di Bursa Efek Indonesia tahun 2012-2014 selama periode pengamatan sebesar 28,45 dengan standart deviasi 1,32. Jarak tidak jauh antara nilai minimum dan maksimum ukuran perusahaan dimana nilai minimum 26,29 dan nilai maksimum sebesar 30,72.

2. Ukuran KAP

Berdasarkan tabel diatas nampak bahwa dari 12 perusahaan pertambangan selama 3 tahun periode pengamatan ukuran KAP pada perusahaan pertambangan yang terdaftar di Bursa Efek Indonesia tahun 2012-2014 selama periode pengamatan sebesar 0,53 dengan standart deviasi 0,51. Jarak tidak jauh antara nilai minimum dan maksimum ukuran perusahaan dimana nilai minimum 0,00 dan nilai maksimum sebesar 1,00 .

3. Solvabilitas

Berdasarkan tabel nampak bahwa dari 12 perusahaan pertambangan selama 3 tahun periode pengamatan ukuran KAP pada perusahaan pertambangan yang terdaftar di Bursa Efek Indonesia tahun 2012-2014 selama periode pengamatan sebesar 1,16 dengan standart deviasi 1,18. Jarak tidak jauh antara nilai

Jurnal Akuntansi Indonesia

46

Vol. 5 No. 1 Januari 2016 
minimum dan maksimum ukuran perusahaan dimana nilai minimum 0,05 dan nilai maksimum sebesar 3,94 .

4. Profitabilitas

Berdasarkan tabel diatas nampak bahwa dari 12 perusahaan pertambangan selama 3 tahun periode pengamatan ukuran KAP pada perusahaan pertambangan yang terdaftar di Bursa Efek Indonesia tahun 2012-2014 selama periode pengamatan sebesar 0,05 dengan standart deviasi 0,08. Jarak tidak jauh antara nilai minimum dan maksimum ukuran perusahaan dimana nilai minimum -0,14 dan nilai maksimum sebesar 0,21.

\section{Uji Asumsi Klasik}

Model regresi yang digunakan akan menunjukkan hubungan yang signifikan dan representative, maka model regresi tersebut memenuhi asumsi klasik regresi, maka asumsi dasar tersebut tidak ada apabila tidak terjadi gejala normalitas, autokorelasi, heteroskedastisitas, dan multikolinearitas diantara variabel bebas dalam regresi tersebut. Dan selanjutnya dilakukan pengujian statistik, yaitu t hitung, $f$ hitung, dan koefisien determinasi $\left(\mathrm{R}^{2}\right)$

1. Uji Normalitas

Pengujian normalitas bertujuan untuk menguji apakah dalam model regresi, variabel pengganggu atau residual memiliki distribusi normal.

Berdasarkan hasil data diatas dapat diketahui bahwa nilai residual untuk data ukuran perusahaan, ukuran KAP, solvabilitas, dan profitabilitas sebesar 0,200 yang berarti > 0,05 signifikansi sehingga semua variabel berdistribusi normal.

2. Uji Multikolinearitas

Uji multikolinearitas bertujuan ntuk menguji apakah dalam model regresi ditemukan adanya korelasi antar variabel bebas. Model regresi yang baik tidak terjadi korelasi antar variabel bebas.

Multikolinearitas dapat dilihat dengan nilai tolerance dan variance inflation factor. Berdasarkan tabel diatas diketahui bahwa semua variabel bebas memiliki nilai tolerance lebih dari 0,10 dan hasil perhitungan VIF variabel bebas adalah lebih kecil dari 10, sehingga dapat disimpulkan bahwa variabel dalam model regresi tidak terjadi multikolinearitas.

3. Uji Autokorelasi

Uji autokorelasi bertujuan untuk menguji apakah dalam suatu model regresi linier ada korelasi antara kesalahan pengganggu pada periode t-1 (sebelumnya).

Dari hasil SPSS menunjukkan bahwa nilai test adalah 2,3172 dengan probabilitas 0,866 signifikan pada 0,05 . Sehingga dinyatakan bahwa model bebas dari masalah autokorelasi atau tidak terjadi autokorelasi.

4. Uji Heteroskedastisitas

Uji heteroskedastisitas bertujuan untuk menguji apakah dalam model regresi terjadi ketidaksamaan variance dan residual satu pengamatan ke pengamatan lain . 
Dari hasil tabel diatas dapat disimpulkan bahwa semua variabel independen yang digunakan dalam penelitian ini tidak terjadi heteroskedastisitas yakni nilai signifikan diatas 0,05.

\section{Pengujian Hipotesis}

1. Analisis Regresi Linier Berganda

Uji regresi berganda dalam penelitian ini dimaksudkan untuk melihat sejauh mana pengaruh dari masingmasing variabel independen mempengaruhi variabel dependen. Berdasarkan hasil uji regresi dapat dibentuk sebuah persamaan berikut :

\section{AUD = 199,429 - 4,702 SIZE + 5,760 KAP + 3,057 SOLVA - 97,621 PROFIT + $\varepsilon$}

Intertpretasi dari regresi diatas adalah sebagai berikut :

a. Nilai koefisien regresi variabel ukuran perusahaan diperoleh sebesar - 4,702 hal ini berarti bahwa apabila kenaikan ukuran perusahaan yang diukur dengan total asset maka akan menurunkan audit delay selama 4,702 hari.

b. Nilai koefisien variabel ukuran KAP diperoleh sebesar 5,760 hal ini berarti apabila perusahaan yang diaudit oleh KAP the Big Four maka audit delay akan naik selama 5,760 hari.

c. Nilai koefisien variabel solvabilitas diperoleh sebesar 3,057 hal ini berarti bahwa setiap kenaikan solvabilitas maka audit delay akan naik selama 3,057 hari.

d. Nilai koefisien variabel ukuran KAP diperoleh sebesar - 97,621 hal ini berarti bahwa apabila profitabilitas mengalami kenaikan maka akan menurunkan audit delay selama 97,621 hari.

2. Uji Layak Model (Uji F)

Pengujian signifikansi parameter simultan digunakan untuk mengetahui apakah secara simultan variabel ukuran perusahaan, ukuran KAP, solvabilitas, dan profitabilitas mempunyai pengaruh yang signifikan atau tidak terhadap variabel audit delay. Berdasarkan hasil pengolahan data dengan bantuan alat analisa statistik. Untuk mengetahui nilai F-tabel, tingkat signifikansi yang digunakan sebesar 5\%. Hasil analisa regresi berganda simultan dapat dilihat sebagai berikut :

Dari hasil uji F didapat nilai probabilitas signifikan 0,000 dibawah nilai kritis 0,05 menunjukkan bahwa terdapat pengaruh ukuran perusahaan, ukuran KAP, solvabilitas, dan profitabilitas berpengaruh terhadap audit delay pada perusahaan pertambangan yang terdaftar di BEl periode tahun 2012 - 2014.

3. Uji Hipotesis Secara Parsial (Uji t)

Uji digunakan untuk mengetahui apakah masing-masing variabel independen berpengaruh atau tidak terhadap variabel dependen. Dalam penelitian diketahui bahwa $n=36$ pada tingkat signifikansi $5 \%$. Pada tingkat kesalahan $(a=0,05)$ dengan menggunakan uji t hitung dari variabel ukuran perusahaan, ukuran KAP, solvabilitas, dan profitabilitas pada perusahaan pertambangan yang terdaftar di BEI tahun 2012 -2014 adalah :

Hasil pada tabel diatas dapat dijelaskan sebagai berikut :

a. Variabel ukuran perusahaan diduga merupakan variabel yang mempengaruhi audit delay. Dari pengujian hipotesis didapatkan nilai sig. variabel ukuran perusahaan sebesar 0,049<0,05 dengan 
demikian dapat disimpulkan bahwa ukuran perusahaan berpengaruh terhadap audit delay. Dengan demikian $\mathbf{H}_{\mathbf{1}}$ diterima.

b. Variabel ukuran KAP diduga merupakan variabel yang mempengaruhi audit delay. Dari pengujian hipotesis didapatkan nilai sig.variabel ukuran KAP sebesar 0,354 >0,05 dengan demikian dapat disimpulkan bahwa ukuran KAP tidak berpengaruh terhadap audit delay. Dengan demikian $\mathbf{H}_{2}$ ditolak.

c. Variabel solvabilitas diduga merupakan variabel yang mempengaruhi audit delay. Dari pengujian hipotesis didapatkan nilai sig. variabel solvabilitas sebesar 0,180>0,05 dengan demikian dapat disimpulkan bahwa solvabilitas tidak berpengaruh terhadap audit delay. Dengan demikian $\mathbf{H}_{\mathbf{3}}$ ditolak.

d. Variabel profitabilitas diduga merupakan variabel yang mempengaruhi audit delay. Dari pengujian hipotesis didapatkan nilai sig. variabel profitabilitas sebesar 0,003 0,05 dengan demikian dapat disimpulkan bahwa ukuran perusahaan berpengaruh terhadap audit delay. Dengan demikian $\mathbf{H}_{4}$ diterima.

4. Uji Koefisien Determinasi $\left(R^{2}\right)$.

Uji koefisien Determinasi $\left(R^{2}\right)$ dilakukan untuk mengukur seberapa jauh kemampuan model dalam menerangkan variabel dependen. Untuk menguji R dapat dilihat pada tabel Model Summary.

Pada tabel 10 diatas dapat diperoleh nilai Adjuster R Square adalah 0,440 - 44,0 \% yang menunjukkan bahwa variabel audit delay dipengaruhi oleh keempat variabel yaitu ukuran perusahaan, ukuran KAP, solvabilitas, dan profitabilitas sebesar $44 \%$. Sedangkan selebihnya $56 \%$ dijelaskan variabel lain

\section{PEMBAHASAN}

\section{Pengaruh Ukuran Perusahaan Terhadap Audit Delay}

Berdasarkan hasil analisis regresi linier berganda variabel ukuran perusahaan 0,049<0,05 sehingga ukuran perusahaan mempunyai pengaruh signifikan terhadap audit delay perusahaan. Maka uji hipotesis 1 yang menyatakan bahwa ukuran perusahaan mempunyai pengaruh yang signifikan terhadap audit delay diterima. Hal ini karena perusahaan yang sudah go public atau perusahaan besar pasti memiliki pengendalian internal yang baik. Selain itu, pada sampel penelitian ini menggunakan sektor pertambangan yang sebagian besar mengekspor hasil tambangnya keluar negeri seperti pada PT. Timah (Persero) Tbk memiliki ukuran perusahaan sebesar 29,68 dengan audit delay 55,00, PT. Tambang Bukit Asam Tbk memiliki ukuran perusahaan 30,20 dengan audit delay 56,00, dan PT. Aneka Tambang Tbk memiliki ukuran perusahaan 30,68 dengan audit delay 64,33, ketiganya memiliki total aset yang cukup besar dengan pengendalian perusahaan yang kuat sehingga audit delay pada ketiga perusahaan ini dapat diminimalisasi.

\section{Pengaruh Ukuran KAP Terhadap Audit Delay}

Berdasarkan hasil analisis regresi linier berganda variabel ukuran KAP 0,354 > 0,05 sehingga ukuran KAP tidak mempunyai pengaruh signifikan terhadap audit delay perusahaan. Maka uji hipotesis 2 yang 
menyatakan bahwa ukuran KAP mempunyai pengaruh yang signifikan terhadap audit delay ditolak. Hal ini karena tidak menjadi jaminan KAP tersebut termasuk KAP the big four hasilnya akan lebih cepat. Dibuktikan dengan hasil penelitian ini yang sampelnya berasal dari sektor pertambangan diantaranya perusahaan PT. Golden Eagle Energy Tbk memiliki audit delay sebesar 86,00 dan PT. Aneka Tambang Tbk memiliki audit delay 64,33 memberikan hasil bahwa kedua perusahaan ini memakai KAP yang termasuk KAP the big four namun diperoleh hasil perusahaan ini memiliki audit delay yang tinggi, sebaliknya PT. Central Omega Resources Tbk memiliki audit delay 49,67. Perusahaan ini menggunakan KAP non the big four namun audit delay nya justru lebih sedikit, sehingga dapat ditarik kesimpulan bahwa tidak menjadi tolak ukur perusahaan yang di audit oleh KAP the big four akan mengalami audit yang lebih sedikit.

\section{Pengaruh Solvabilitas Terhadap Audit Delay}

Berdasarkan hasil analisis regresi linier berganda variabel solvabilitas 0,180 $>0,05$ sehingga solvabilitas tidak mempunyai pengaruh signifikan terhadap audit delay perusahaan. Maka uji hipotesis 3 yang menyatakan bahwa solvabilitas mempunyai pengaruh yang signifikan terhadap audit delay ditolak. Hal ini karena jika perusahaan memiliki pengendalian internal yang kuat maka akan mengurangi tingkat kesalahan dalam penyajian laporan seperti akun-akun hutang. Sampel pada penelitian ini adalah perusahaan tambang seperti PT. Samindo Resources Tbk memiliki solvabilitas sebesar 2,04 dengan audit delay 78,00, PT. Citatah Tbk memiliki solvabilitas sebesar 3,00 dengan audit delay sebesar 71,33, dan PT. Radiant Utama Interinsco Tbk memiliki solvabilitas sebesar 3,63 dengan audit delay 83,00, ketiga perusahaan ini memiliki solvabilitas yang tinggi diikuti dengan audit delay yang tinggi sehingga dapat disimpulkan bahwa solvabilitas tidak mempengaruhi audit delay.

\section{Pengaruh Profitabilitas Terhadap Audit Delay}

Berdasarkan hasil analisis regresi linier berganda variabel profitabilitas 0,003 $<0,05$ sehing ga profitabilitas mempunyai pengaruh signifikan terhadap audit delay perusahaan. Maka uji hipotesis 4 yang menyatakan bahwa profitabilitas mempunyai pengaruh yang signifikan terhadap audit delay diterima.

Perusahaan dengan profitabilitas yang tinggi cenderung membutuhkan waktu pengauditan laporan keuangan yang lebih cepat karena adanya tuntutan untuk menyampaikan kabar baik tersebut secepatnya kepada publik. Sama halnya dengan hasil penelitian ini pada PT. Samindo Resources Tbk memiliki profitabilitas 0,09 dengan audit delay 78,00, PT. Central Omega Resources memiliki profitabilitas sebesar 0,12 dengan audit delay 49,67 , dan PT. Tambang Batubara Bukit Asam Tbk memiliki profitabilitas sebesar 0,16 dengan audit delay 56,00. Membuktikan bahwa semakin tinggi profitabilitas perusahaan semakin rendah audit delaynya, itu artinya profitabilitas berpengaruh secara signifikan terhadap audit delay. 


\section{PENUTUP}

\section{Kesimpulan}

Hasil penelitian menunjukkan bahwa ukuran perusahaan dan profitabilitas berpengaruh terhadap audit delay, sedangkan ukuran KAP dan solvabilitas tidak berpengaruh terhadap audit delay.

\section{Saran}

Beberapa saran yang dapat diberikan antara lain (1) Bagi Perusahaan Pertambangan pada hasil penelitian ini yang berpengaruh signifikan terhadap audit delay adalah variabel ukuran perusahaan dan profitabilitas. Diharapkan pihak manajemen perusahaan memperhatikan dua faktor tersebut agar dapat mengurangi audit delay dalam pelaporan keuangan. (2) Bagi Investor penelitian ini diharapkan dapat membantu calon investor yang akan menanamkan modalnya agar lebih tepat dalam memilih perusahaan. (3) Bagi Akademisi penelitian ini diharapkan menjadi bahan pertimbangan bagi peneliti yang akan datang agar dapat menentukan faktorfaktor apa saja yang mempengaruhi audit delay.

\section{Keterbatasan Penelitian}

Penelitian yang telah dilakukan pada dasarnya memiliki keterbatasan dan kelemahan yang memerlukan penyempurnaan di masa yang akan datang, antara lain (1) Berdasarkan hasil dari adjusted $\mathrm{R}^{2}$ sebesar 44,0\% , nilai adjusted $\mathrm{R}^{2}$ yang masih rendah mengindikasikan masih terdapat variabel independen yang belum mempengaruhi audit delay. (2) Variabel bebas dalam penelitian ini hanya menggunakan satu proksi dalam melakukan pengujian terhadap faktor-faktor yang berpengaruh terhadap audit delay. (3) Dalam penelitian ini terdapat dua variabel yang hipotesanya tidak diterima yang disebabkan oleh pengendalian internal perusahaan yang kurang baik sehingga berdampak pada audit delay .

\section{Agenda Penelitian Yang Akan Datang}

Untuk penelitian yang akan datang mengacu pada keterbatasan penelitian, maka diajukan saran yaitu bagi penelitian selanjutnya diharapkan dapat mempertimbangkan untuk menambahkan variabel bebas lain yang diduga berpengaruh secara signifikan terhadap ketepatan waktu penyampaian laporan keuangan. 


\section{DAFTAR PUSTAKA}

Aryaningsih, Ni Nengah Devi dan I Ketut Budhiarta. 2014. Pengaruh Total Aset, Tingkat Solvabilitas dan Opini Audit pada Audit Delay. E-Jurnal Akuntansi Universitas Udayana, Vol. 3, No. 3;747-647.

Baridwan, Zaki. 2004. Intermediate Accounting, Edisi 8, Yogyakarta: BPFE Yogyakarta.

Estrini, Dwi Hayu dan Herry Laksito. 2013. "Analisis Faktor-Faktor yang mempengaruhi Audit Delay (Study Empiris Pada Perusahaan Manufaktur yang terdaftar di BEI Tahun 2009-2011)". Diponegoro Journal Of Accounting. Vol. 2, No. 2.

Febrianty. 2011"Faktor-Faktor Yang Berpengaruh Terhadap Audit Delay Perusahaan Sektor Perdagangan yang Terdaftar di BEI Periode 2007-2009". Jurnal ekonomi dan Informasi Akuntansi (Jenius). Vol 1, No. 3;September 2011.

Ghozali, Imam. 2011. Aplikasi Analisis Multivariate dengan Program IBM SPSS 19, Edisi 5, Semarang ; Badan Penerbit Universitas Diponegoro.

Iskandar, Meylisa Januar dan Estralita Trisnawati. 2010. "Faktor-Faktor yang Mempengaruhi Audit Report Lag pada Perusahaan yang Terdaftar di Bursa Efek Indonesia". Jurnal Bisnis dan Akuntansi. Vol. 12, No. 3, Desember 2010;175-186. Universitas Tarumanegara.

Kartika, Andi. 2009. "Faktor-Faktor yan Mempengaruhi Audit Delay di Indonesia (Studi Empiris pada PerusahaanPerusahaan LQ 45 yang Terdaftar di Bursa Efek Jakarta)". Jurnal Bisnis dan Ekonomi. Vol. 16, No. 1 Maret 2009;1-17. Universitas Stikubank Semarang.

Kusumawardani, Fitria. 2012. "Faktor-Faktor yang Mempengaruhi Audit Delay pada Perusahaan Manufaktur". Accounting Analysis Journal. Universitas Negeri Semarang.

Lianto, Novice dan Budi Hartono Kusuma. 2010. "Faktor-Faktor yang Berpengaruh terhadap Audit Report Lag". Jurnal Bisnis dan Akuntansi. Vol. 12, No. 2, Agustus 2010;97-106. Universitas Tarumanegara.

Mulyadi. 2002. Auditing Buku1. Jakarta: Salemba Empat.

Prabowo, Pebi Putra Tri dan Marsono. 2013. "Faktor-faktor Yang Mempengaruhi Audit Delay". Diponegoro Journal of Accounting. Vol. 2, No.1; 1-11

Priyatno, Duwi. 2014. Pengolah Data Terpraktis SPSS 22. Yogyakarta: ANDI.

Puspitasari, Elen dan Anggraeni Nurmala Sari. 2012. "Pengaruh Karakteristik Perusahaan Terhadap Lamanya Waktu Penyelesaian Audit (Audit Delay) Pada Perusahaan Manufaktur Yang Terdaftar di Bursa Efek Indonesia". Jurnal Akuntansi dan Auditing. Vol. 9, No. 1.

Rachmawati, Sistya. 2008. "Pengaruh Faktor Internal Dan Eksternal Perusahaan Terhadap Audit Delay dan Timeliness". Jurnal Akuntansi dan Keuangan. Vol. 10, No. 1, Mei 2008;1-10.

Ratnawaty dan Toto Sugiharto.2005. " Audit Delay Pada Industri Real Estate dan Properti yang Terdaftar di Bursa Efek Jakarta dan Faktor yang Mempengaruhi". Proceeding Seminar Nasional PESAT 2005, Jakarta, 23-24 Agustus 2005.

Sulthoni, Moch. 2012. “Determinan Audit Delay dan Pengaruhnya Terhadap Reaksi Investor (Studi Empiris pada Perusahaan yang Listing di BEI Tahun 2007-2008)". Jurnal Akuntansi dan Ekonomi Bisnis. Vol. 1, No.1. 
Susilawati, Christine Dwi Karya, Lidya Agustina, dan Tania Prameswari. 2012. “Audit Delay Pada Perusahaan

Consumer Good Industry di Bursa Efek Indonesia (Periode 2008-2010)". Jurnal IImiah Akuntansi. No.10,

Tahun ke-4, Januari-April 2012;19-30.

www.bapepam.go.id, diakses pada 18 Mei 2015.

www.cnnindonesia.com, diakses tanggal 28 Mei 2015.

www.idx.co.id, diakses pada 30 Mei 2015. 
LAMPIRAN

Tabel 1

Proses Purposive Sampling Penelitian

\begin{tabular}{lc}
\hline \multicolumn{1}{c}{ Kriteria Sample Penelitian } & Total \\
\hline $\begin{array}{l}\text { Jumlah perusahaan pertambangan yang terdaftar di Bursa Efek Indonesia pada } \\
\text { periode tahun } 2012-2014 .\end{array}$ & $\mathbf{3 9}$ \\
\hline $\begin{array}{l}\text { Perusahaan yang tidak menerbitkan laporan keuangan auditan lengkap secara } \\
\text { berturut - turut pada periode tahun 2012 - 2014. }\end{array}$ & $\mathbf{1 2 )}$ \\
\hline $\begin{array}{l}\text { Perusahaan yang menerbitkan laporan keuangan menggunakan mata uang asing. } \\
\text { Perusahaan sample (12) dikalikan dengan periode pengamatan (3) }\end{array}$ & $\mathbf{3 6}$ \\
\hline
\end{tabular}

Sumber : Data diolah, 2015

\section{Statistik Deskriptif}

Sebelum dilakukan pengujian regresi linier berganda pertama kali akan dilakukan analisis deskriptif.

Tabel 2

Descriptive Statistics

\begin{tabular}{lccccccc}
\hline & $\mathrm{N}$ & Minimum & Maximum & \multicolumn{2}{c}{ Mean } & $\begin{array}{c}\text { Std. } \\
\text { Deviation }\end{array}$ & Variance \\
\cline { 2 - 9 } & Statistic & Statistic & Statistic & Statistic & Std. Error & Statistic & Statistic \\
\hline AuditDelay & 36 & 17,00 & 87,00 & 66,9167 & 2,86450 & 17,18700 & 295,393 \\
\hline UkuranPerusahaan & 36 & 26,29 & 30,72 & 28,4533 &, 21987 & 1,31924 & 1,740 \\
\hline UkuranKAP & 36 &, 00 & 1,00 &, 5278 &, 08438 &, 50631 &, 256 \\
\hline Solvabilitas & 36 &, 05 & 3,94 & 1,1644 &, 19591 & 1,17548 & 1,382 \\
\hline Profitabilitas & 36 &,- 14 &, 21 &, 0544 &, 01328 &, 07969 &, 006 \\
\hline Valid N (listwise) & 36 & & & & & & \\
\hline
\end{tabular}

Sumber : data sekunder yang diolah, 2015

Tabel 3

\begin{tabular}{|c|c|c|}
\hline \multicolumn{3}{|c|}{ One-Sample Kolmogorov-Smirnov Test } \\
\hline \multicolumn{3}{|c|}{ Unstandardized Residual } \\
\hline $\mathrm{N}$ & & 36 \\
\hline \multirow{2}{*}{ Normal Parameters ${ }^{\mathrm{a}, \mathrm{b}}$} & Mean &, 0000000 \\
\hline & Std. Deviation & 12,10160954 \\
\hline \multirow{3}{*}{ Most Extreme Differences } & Absolute & , 111 \\
\hline & Positive & 085 \\
\hline & Negative &,- 111 \\
\hline Test Statistic & &, 111 \\
\hline Asymp. Sig. (2-tailed) & & $200^{c, d}$ \\
\hline \multicolumn{3}{|l|}{ a. Test distribution is Normal. } \\
\hline \multicolumn{3}{|l|}{ b. Calculated from data. } \\
\hline c. Lilliefors Significance Co & n. & \\
\hline
\end{tabular}


Tabel 4

Uji Multikolinearitas

\begin{tabular}{|c|c|c|c|c|c|c|c|c|}
\hline \multicolumn{9}{|c|}{$\begin{array}{c}\text { Coefficients }^{\mathrm{a}} \\
\end{array}$} \\
\hline \multirow{2}{*}{\multicolumn{2}{|c|}{ Model }} & \multicolumn{2}{|c|}{$\begin{array}{l}\text { Unstandardized } \\
\text { Coefficients }\end{array}$} & \multirow{2}{*}{$\begin{array}{c}\text { Standardized } \\
\text { Coefficients } \\
\text { Beta } \\
\end{array}$} & \multirow{2}{*}{$\mathrm{t}$} & \multirow{2}{*}{ Sig. } & \multicolumn{2}{|c|}{ Collinearity Statistics } \\
\hline & & B & $\begin{array}{l}\text { Std. } \\
\text { Error }\end{array}$ & & & & Tolerance & VIF \\
\hline & (Constant) & 199,429 & 63,345 & & 3,148 & 004 & & \\
\hline & UkuranPerusahaan & $-4,702$ & 2,300 &,- 361 & $-2,045$ & 049 &, 513 & 1,948 \\
\hline \multirow[t]{3}{*}{1} & UkuranKAP & 5,760 & 6,127 & , 170 & 940 & ,354 & ,491 & 2,037 \\
\hline & Solvabilitas & 3,057 & 2,230 & ,209 & 1,371 & 180 & ,688 & 1,454 \\
\hline & Profitabilitas & $-97,621$ & 30,346 &,- 453 & $-3,217$ & ,003 & 808 & 1,238 \\
\hline
\end{tabular}

a. Dependent Variable: AuditDelay

Tabel 5

Uji autokorelasi

\begin{tabular}{lr}
\hline \multicolumn{2}{c}{ Runs Test } \\
\hline \multicolumn{1}{c}{ Unstandardized Residual } \\
\hline Test Value $^{\mathrm{a}}$ & 2,31972 \\
\hline Cases $<$ Test Value $^{2}$ & 18 \\
\hline Cases $>=$ Test Value & 18 \\
\hline Total Cases & 36 \\
\hline Number of Runs & 18 \\
\hline
\end{tabular}

Tabel 6

Hasil Uji Heteroskedastisitas

Coefficients $^{a}$

\begin{tabular}{|c|c|c|c|c|c|c|}
\hline \multirow{2}{*}{\multicolumn{2}{|c|}{ Model }} & \multicolumn{2}{|c|}{ Unstandardized Coefficients } & \multirow{2}{*}{$\begin{array}{l}\text { Standardized } \\
\text { Beta }\end{array}$} & \multirow{2}{*}{$\mathrm{T}$} & \multirow{2}{*}{ Sig. } \\
\hline & & B & Std. Error & & & \\
\hline \multirow{5}{*}{1} & (Constant) & 55,473 & 33,805 & & 1,641 & 111 \\
\hline & UkuranPerusahaan & $-1,721$ & 1,227 &,- 326 & $-1,403$ & 171 \\
\hline & UkuranKAP & 4,126 & 3,270 & ,300 & 1,262 & ,216 \\
\hline & Solvabilitas &,- 324 & 1,190 &,- 055 &,- 272 & ,787 \\
\hline & Profitabilitas & 26,876 & 16,195 & ,308 & 1,660 & 107 \\
\hline
\end{tabular}

Sumber : Data sekunder yang diolah, 2015 
Tabel 8

\begin{tabular}{|c|c|c|c|c|c|c|}
\hline \multicolumn{7}{|c|}{$\begin{array}{c}\text { Uji Layak Model (Uji F) } \\
\text { ANOVA }^{\text {ANO }}\end{array}$} \\
\hline Model & & Sum of Squares & Df & Mean Square & $\mathrm{F}$ & Sig. \\
\hline \multirow{3}{*}{1} & Regression & 5213,037 & 4 & 1303,259 & 7,882 &, $000^{\mathrm{b}}$ \\
\hline & Residual & 5125,713 & 31 & 165,346 & & \\
\hline & Total & 10338,750 & 35 & & & \\
\hline
\end{tabular}

a. Dependent Variable: AuditDelay

b. Predictors: (Constant), Profitabilitas, UkuranKAP, Solvabilitas, UkuranPerusahaan

Sumber : data sekunder yang diolah, 2015

Tabel 9

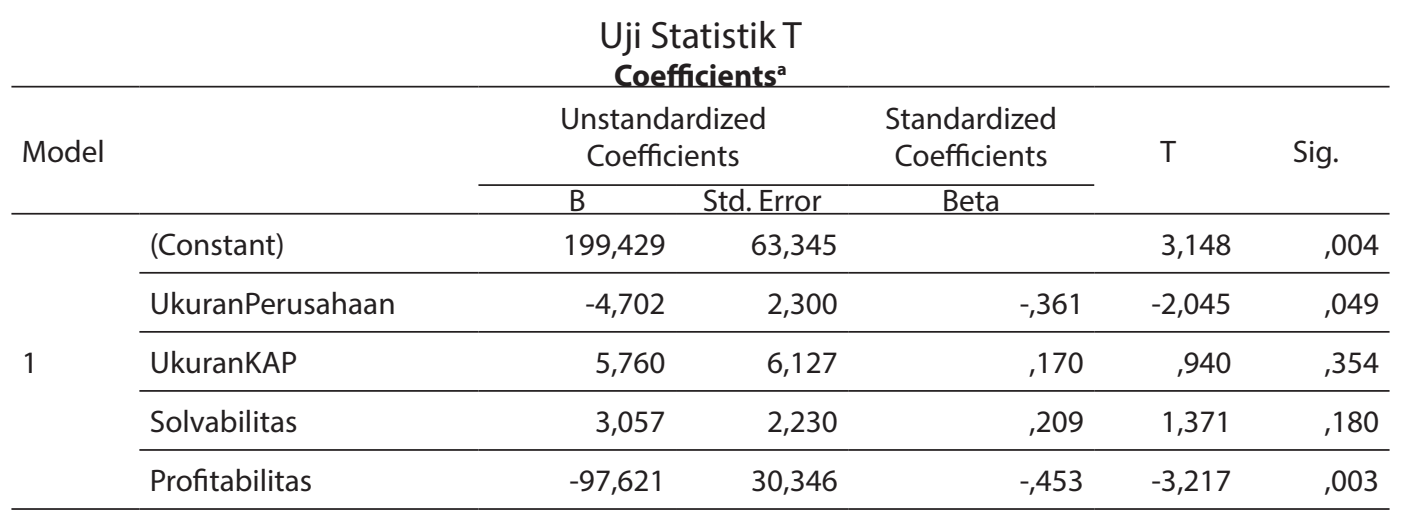

a. Dependent Variable: AuditDelay

Sumber : data sekunder yang diolah, 2015

Tabel 10

Uji Koefisien Determinasi $\left(R^{2}\right)$

Model Summaryb

\begin{tabular}{|c|c|c|c|c|}
\hline Model & $\mathrm{R}$ & R Square & $\begin{array}{l}\text { Adjusted R } \\
\text { Square }\end{array}$ & Std. Error of the Estimate \\
\hline 1 &, $710^{\mathrm{a}}$ & ,504 & ,440 & 12,85868 \\
\hline
\end{tabular}

a. Predictors: (Constant), Profitabilitas, UkuranKAP, Solvabilitas, UkuranPerusahaan

b. Dependent Variable: AuditDelay

Sumber : data sekunder yang diolah, 2015 